\title{
Alternative medicine: cost and subjective benefit in rheumatoid arthritis
}

\author{
T PULLAR, H A CAPELL, A MILLAR, R G BROOKS
}

\begin{abstract}
Seventy-eight patients with seropositive rheumatoid arthritis were asked about money spent in an attempt to help their arthritis. This included expenditure on alternative medicine, aids for the home, and conventional medicine. Most money was spent on, and most benefit was derived from, aids for the home. Sixty per cent of the patients had tried alternative medicine, but expenditure on this was relatively low and only a small proportion found it helpful.
\end{abstract}

\section{Introduction}

A BBC2 television programme in August 1981, Brass tacks: a better alternative, suggested that alternative medicine may have more to offer patients with chronic rheumatic disorders than conventional treatment. Most forms of alternative medicine are not available under the National Health Service (NHS), and several reports have indicated that large sums of money are spent on alternative medicine each year. ${ }^{1-3}$ There is, however, little information about consumer satisfaction or precise diagnosis of patients spending this money.

\footnotetext{
Centre for Rheumatic Diseases, University Department of Medicine, Glasgow Royal Infirmary, Glasgow G4 OEH

T PULLAR, MB, MRCP, registrar

H.A CAPELL, MB, MRCP, consultant physician

Department of Economics, University of Strathclyde, Glasgow G1 1XW

A MILLAR, BA, research assistant

R G BROOKS, BA, MSC, lecturer
}

At our regional rheumatic diseases unit, which is concerned mainly with major inflammatory joint disease, patients with rheumatoid arthritis are the most easily defined group. They may already be at a financial disadvantage, and any additional burden needs careful scrutiny. We studied patients with rheumatoid arthritis attending this unit to ascertain expenditure on, and benefit derived from, alternative medicine, and compared this with expenditure on aids and conventional treatment.

\section{Methods and materials}

Seventy-eight women patients suffering from classical (seropositive) rheumatoid arthritis were studied. At the time of the study 50 patients were receiving second-line treatment in addition to non-steroidal anti-inflammatory agents (NSAIDs). Most were being followed up at weekly or four-weekly intervals and a few three-monthly. The 28 other patients were receiving only first-line treatment (NSAIDs) and were attending the clinic at monthly to six-monthly intervals. Information was obtained using a standard questionnaire at the time of a clinic visit. All patients who agreed to help were interviewed by $\mathrm{AM}$, who has no medical training, in a private room adjacent to the clinic. The atmosphere was deliberately informal and no comment was made about the attitude of the staff to various remedies. Age and duration of disease were noted, and severity of rheumatoid arthritis was assessed by a pain score (visual analogue scale), erythrocyte sedimentation rate, and rheumatoid factor titre. Patients were asked about expenditure on various forms of alternative medicine over the past one and five years. We did not want to single out alternative medicine and patients were therefore asked about functional aids to alleviate their arthritic problems and about the cost of transport to the rheumatology clinics and prescription charges. For each item of expenditure the patient was asked to score benefit derived: a lot, a little, none, made condition a bit worse, or a lot worse. 
They were also asked whether they received any State financial aid. Information about income was sought and inquiries made concerning financial aid from their families, and about the patient's (and husband's or father's) occupation in order to assess social class.

\section{Results}

Breakdown of the type of expenditure by the 78 patients and subjective benefit over one year is shown in table I. Of the patients receiving first-line treatment, $25 \%$ gained no benefit from prescribed drugs, $43 \%$ gained a little benefit, and $32 \%$ gained a lot. Eighteen per cent of the patients on second-line treatment gained no benefit from prescribed drugs, $48 \%$ gained a little benefit, and $34 \%$ gained a lot of benefit. Results over five years are shown in table II, and the relative expenditure is shown in the figure. The first- and second-line treatment groups were similar and are therefore grouped together. Findings over five years were similar, though patients found recall more difficult. Most of the money spent by patients on their arthritis was on aids to daily living ( $£ 8123$ in one year). This figure was greater than total patient expenditure on all other treatments ( $£ 3580$ in one year). Aids comprised both those prescribed by the hospital or domiciliary occupational therapist and those which the patients bought without professional advice. These included such diverse items as can openers, special cutlery, toilet and washing aids, and washing machines; most expenditure was on large items (table III).

TABLE I-Expenditure pattern over one year before interview

\begin{tabular}{|c|c|c|c|c|c|c|}
\hline & & \multirow{2}{*}{$\begin{array}{l}\text { No who } \\
\text { paid }\end{array}$} & \multirow{2}{*}{$\begin{array}{c}\text { Total } \\
\text { money } \\
\text { spent } \\
(£)\end{array}$} & \multicolumn{3}{|c|}{$\begin{array}{l}\text { Benefit derived } \\
\text { ( } \% \text { of those who paid) }\end{array}$} \\
\hline & & & & None & A little & A lot \\
\hline $\begin{array}{l}\text { Vitamins ... } \\
\text { Special diet } \\
\text { Herbal remedies.. } \\
\text { Rubs } . \\
\text { Copper bracelets } \\
\text { Acupuncture } \\
\text { Aids for the home } \\
\text { Prescriptions } \\
\text { Travel to the clinic }\end{array}$ & $\begin{array}{l}\ldots \\
\because \\
\because \\
\because \\
\because \\
\cdots\end{array}$ & $\begin{array}{r}24 \\
9 \\
20 \\
29 \\
5 \\
4 \\
37 \\
53 \\
44\end{array}$ & $\begin{array}{r}406 \\
280 \\
248 \\
156 \\
16 \\
280 \\
8123 \\
902 \\
1292\end{array}$ & $\begin{array}{r}33 \\
56 \\
70 \\
31 \\
80 \\
50 \\
0 \\
23\end{array}$ & $\begin{array}{r}50 \\
33 \\
20 \\
45 \\
20 \\
50 \\
0 \\
42\end{array}$ & $\begin{array}{r}17 \\
11 \\
10 \\
24 \\
0 \\
0 \\
100 \\
36\end{array}$ \\
\hline
\end{tabular}

TABLE II-Expenditure pattern over five years before interview

\begin{tabular}{|c|c|c|c|c|c|c|}
\hline & \multirow{2}{*}{\multicolumn{2}{|c|}{$\begin{array}{l}\text { No who } \\
\text { paid }\end{array}$}} & \multirow{2}{*}{$\begin{array}{l}\text { Total } \\
\text { money } \\
\text { spent } \\
(f)\end{array}$} & \multicolumn{3}{|c|}{$\begin{array}{l}\text { Benefit derived } \\
\text { (\% of those who paid) }\end{array}$} \\
\hline & & & & None & A little & A lot \\
\hline $\begin{array}{l}\text { Vitamins .. } \\
\text { Special diet } \\
\text { Herbal remedies . . } \\
\text { Rubs .. } \\
\text { Copper bracelets } \\
\text { Acupuncture } \quad .\end{array}$ & $\begin{array}{l}\cdots \\
\cdots \\
\cdots \\
\cdots\end{array}$ & $\begin{array}{r}30 \\
12 \\
23 \\
32 \\
6 \\
11\end{array}$ & $\begin{array}{r}1289 \\
1135 \\
588 \\
657 \\
17 \\
537\end{array}$ & \multirow{2}{*}{$\begin{array}{c}10 \\
6 \\
17 \\
11 \\
5 \\
7+1 \\
\text { (lot worse) } \\
0 \\
0 \\
1 \\
0\end{array}$} & $\begin{array}{r}15 \\
4 \\
4 \\
13 \\
1 \\
3\end{array}$ & $\begin{array}{l}5 \\
2 \\
2 \\
8 \\
0 \\
0\end{array}$ \\
\hline $\begin{array}{l}\text { Aids for the home } \\
\text { Vibrating chairs .. } \\
\text { Homeopathy } \quad . \\
\text { Osteopathy } \quad .\end{array}$ & $\begin{array}{l}\cdots \\
\cdots \\
\cdots\end{array}$ & $\begin{array}{r}48 \\
2 \\
1 \\
0\end{array}$ & $\begin{array}{c}21337 \\
151 \\
30\end{array}$ & & $\begin{array}{l}0 \\
2 \\
0 \\
0\end{array}$ & $\begin{array}{r}48 \\
0 \\
0 \\
0\end{array}$ \\
\hline
\end{tabular}

TABLE III-Aids prescribed and bought by patients

\begin{tabular}{llc}
\hline Class of aids & \multicolumn{1}{c}{ Examples } & No of patients \\
\hline Kitchen & $\begin{array}{c}\text { Electric can opener, pots with modified handles, } \\
\text { liquidiser, bottle opener, electric knife, potato }\end{array}$ & 53 \\
peeler, kettle holder & $\begin{array}{c}\text { Electric razor, shower, raised toilet seat, bath } \\
\text { mat, bath seat }\end{array}$ & 37 \\
Hothroom & $\begin{array}{l}\text { Vacuum cleaner, trolley, large door knobs, } \\
\text { ejector seat, rocking chair, high chair }\end{array}$ & 39 \\
$\begin{array}{l}\text { Dressing } \\
\text { Mobility }\end{array}$ & $\begin{array}{l}\text { Long-handled comb, tongs } \\
\text { Wheelchair, walking stick, bannisters }\end{array}$ & 7 \\
\hline
\end{tabular}

Forty-seven patients paid for some form of alternative medicine in the year before the interview. Most patients (74) were prepared to volunteer information about income. The amount of financial help from the patient's family correlated with total expenditure, and when this was broken down into aids and non-aids showed a strong correlation with money spent on aids. There was no correlation between household income, social class, or State financial help and money spent. Only one patient thought that his condition had been made worse by any treatment-namely, acupuncture. Satisfaction was greatest with aids, followed by drugs and rubs, while little benefit was reported from diet, herbal remedies, or copper bracelets.

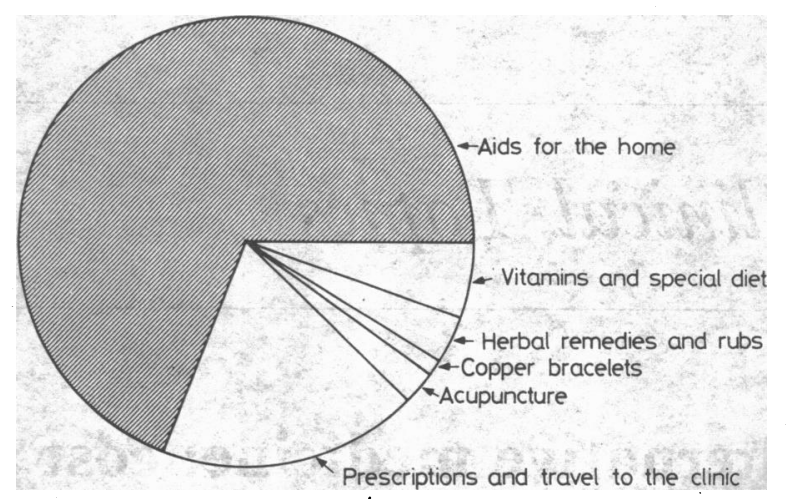

Relative expenditure by patient on various forms of treatment in past one year.

Thirty-four patients travelled to the clinics by ambulance, the remainder using either public or private transport. The cost per journey was similar for patients on first- or second-line treatment but those on second-line treatment spent more per month (mean cost per patient per month $=£ 3 \cdot 24$ for those on second-line treatment and $£ 1.06$ for those on first-line treatment alone). Thirty-three $(42 \%)$ patients received a mobility allowance; $39(50 \%)$ an invalidity allowance; $37(47 \%)$ a travel card; nine $(12 \%)$ an attendance allowance; $34(43 \%)$ ambulance transport; and 25 (32\%) exemption from prescription charges. The form of State financial aid seemed to be unrelated to severity of disease. Those not receiving exemption from prescription charges spent an average of $£ 16.34$ (first-line patients) and $£ 17.34$ (second-line patients) per year on prescriptions.

\section{Discussion}

This study was performed to assess whether or not expenditure on alternative medicine placed a financial burden on patients with rheumatoid arthritis and to ascertain subjective benefit derived. Only women with seropositive rheumatoid arthritis were studied in order to obtain as homogeneous a group as possible. We were surprised at how little money had been spent on treatment that we classify broadly as alternative medicine-namely, treatment that a.conventional unit is unlikely to prescribe. Copper bracelets, which are cheap, and acupuncture, which is expensive, did not produce much benefit. Only rubs approached conventional treatment in giving subjective relief. Both travel to the clinic and prescription charges represent recurring expenses for most patients with rheumatoid arthritis.

These patients are highly selected since they have wellcharacterised disease and attend a traditional unit. Thus, by implication, they might be presumed to accept traditional concepts of medical care. Nevertheless, when asked by patients about the advisability of alternative medicine this clinic offers no opposition provided that there is no danger entailed and the 
patient can afford the planned regimen. The usual approach is to state that there is no scientific evidence for or against such treatments.

It is possible that patients with non-specific rheumatic pains in whom no diagnosis is made may resort, in desperation, to alternative medicine more frequently and account for the quoted statistics of extensive expenditure. ${ }^{1-3}$ We do not have immediate access to such a patient population and cannot, therefore, make any meaningful comments. Extension of the study by collaboration with family doctors to include such a population is planned.

We asked about all expenses incurred because of arthritis since we wished to view alternative medicine expenditure in the context of the overall financial implications of rheumatoid arthritis. The total amount spent on aids was surprisingly large and it is striking that by far the greatest benefit was gained from these aids for the home with prescribed medicine a poor second. It is, perhaps, a little disheartening for the rheumatologist that the number of patients who thought that they gained benefit from second-line treatment was no different from those receiving only first-line treatment. Presumably, however, the latter had less severe disease at the outset.

When patients were given the chance to "vote with their purses" they clearly opted for home aids. This is despite the fact that the Centre for Rheumatic Diseases, which fulfils a regional role and serves a population of 2.8 million, has only one part-time occupational therapist and Glasgow has no aids centre. The satisfaction with aids was even more surprising since a survey conducted in Leeds ${ }^{4}$ suggested that many patients were not entirely satisfied with aids purchased. In that study, however, only aids were assessed and the emphasis of questioning was different. The Leeds group was looking for complete satisfaction whereas we were assessing relative benefits, and even a "lot of benefit" does not imply perfection.

It is possible that the expectations of patients with rheumatoid arthritis are more realistic with respect to consumer durables such as potato peelers, showers, raised toilet seats, and washing machines than they are about "miracle" drugs or treatments, where the popular press often misrepresents the facts. It has been shown previously that expectations are important regarding final outcome. ${ }^{5}$ Optimism is important in chronic "incurable" disorders but needs to be tempered with realism; unsubstantiated reports might induce false hope and subsequent disappointment.

Until a truly dramatic solution is found for the disability caused by rheumatoid arthritis, the provision of practical aids to daily living seems worthy of emphasis to patients, their relatives, and those concerned in their care.

\section{References}

1 Arthritis Foundation. Annual report 1975. London: Arthritis Foundation 1975.

2 Decker JL. The final common pathway. Arthritis Rheum 1973;16:765-70.

${ }^{3}$ Rosie G. Can this be relieved by a mussel ? The Scotsman Magazine 1981; 2, No 10:6-10.

4 Chamberlain MA, Stowe J. A survey of personal aids supplied by post to arthritics. Rheumatol Rehabil 1980;19:246-51.

5 Burton KE, Wright V, Richards J. Patients' expectations in relation to outcome of total hip replacement surgery. Ann Rheum Dis 1979;38:471-4.

(Accepted 5 September 1982)

\title{
Family Medicine
}

\section{Thamesmead: lessons learnt}

\author{
P M HIGGINS
}

Our first priority as general practitioners in Thamesmead in 1968 was to establish the practice on the best possible footing, but we had also to consider our future responsibilities for teaching students. General practice was a new academic discipline, and I had no recent experience of teaching students. I had much to learn about my work as a general practitioner and about teaching. At that time a voluntary attachment was the only experience of general practice offered to students at Guy's Hospital Medical School, and about one in 10 students took advantage of it. I visited all the practices near Guy's, and a few allowed us to take students to talk with patients in their homes or at the practice premises each week; we also taught in the medical outpatients department.

Vocational training for general practice was on the way, and practices and general practitioners who were prepared for training would also be prepared for students. What I learnt

Guy's Hospital Medical School, London SE1 9RT

P M HIGGINS, FRCP, FRCGP, Bernard Sunley professor of general practice about training would help with teaching students. In 1969 I became secretary and later chairman of the education committee of the South-east England Faculty of the Royal College of General Practitioners, which had compiled a register of doctors who were willing to take students; this was updated and extended. Plans were well advanced for the region's first training scheme at Cuckfield and proposals for Thanet and for Tunbridge Wells were under negotiation. The general practice research unit at Guy's became the department of general practice in 1969. In 1970 I was appointed regional adviser in general practice and launched London's first course for teachers in general practice. For five years I was tutor to this three-term course, which continues in a shortened form. In 1974 the Bernard Sunley Foundation generously offered Guy's a yearly sum of money, initially for 10 years, to establish a chair of general practice. All the general practitioners in Thamesmead have part-time appointments in the department's undergraduate section and thus make up its teaching staff. The department also has a postgraduate section funded by the Postgraduate Medical Federation. There are now four associate advisers in post; one has a special responsibility for continuing education in inner London, another for research and audit, and a third for trainers and course organisers. 